\title{
Suitability of Drinking Water in and around Clay Mines in Northern Kerala, India
}

\author{
Gopesh G K ${ }^{1}$, R Vineetha Pillai ${ }^{2}$ \\ ${ }^{1}$ Research and Development Cell, Bharathiar University, Coimbatore \\ ${ }^{2}$ Department of Chemistry, Kohima Science College, Nagaland
}

\begin{abstract}
The mining activity provides significant benefits to society with strong passions, but it should be sustainably planned and controlled. Clay mining activity is widely used in all parts of the world which impact on drying of wells and rehabilitation problems in large scale. Clay is a natural and earthy fine-grained material which contains a significant amount of minerals in the form of crystalline hydrous silicate material. The degradation in the level of clay causes severe impact on water hence this paper intends to evaluate the impact of clay mining on the physical and chemical characteristics of drinking water sources in and around the mining zone of Payangadi - North of Kannur, Kerala. This research uses water samples collected in pre-monsoon and post-monsoon period for examining various physicochemical characteristics like $\mathrm{pH}$, acidity, salinity, hardness, silica, $\mathrm{Mg}, \mathrm{Cl}-, \mathrm{SO}_{4}^{2-}$, total dissolved solids (TDS), and chemical oxygen demand (COD). APHA (American public health association) 2012 test method used for analytical purposes and the permissible limits for the physic-chemical parameters of the water samples based on IS-10500:2012 and WHO 2012. The findings of the study revealed that the quality of drinking water is considerably affected by clay mining activity wherein only an average of $30.09 \%$ post-monsoon water samples is found to be within the permissible limit as stated in IS-10500:2012 and WHO 2012.
\end{abstract}

Keywords: Groundwater TDS, Salinity, pH, BDL, Physicochemical Properties

\section{Introduction}

Water is consider as one of the most precious resources for all the living organisms on Earth. They are very prominent and efficient in the molding earth's topography by carrying enormous quantities of water from the land towards the sea. Anthropogenic activities like the discharge of industrial, domestic and major wastes have caused problems to the rivers in the form of pollution. To evaluate the suitability of drinking water existing methods of analysis have not given a global vision on temporal and spatial trends for the overall water quality. To measure the suitability of water for drinking Water Quality Index (WQI) is a useful tool for conveying information regarding the pollution status of the river. Initially, Horton ${ }^{[1]}$ and Brown et al. ${ }^{[2]}$ evaluated the standard for assessing the suitability of drinking water. In existing, several numerous methods were developed for calculating the quality of water. Also, many researchers developed a mathematical based numerical expression for evaluating the quality of the water. ${ }^{[2-7]}$ Generally to understand the clear understanding of the water quality indexing tools were used for better transformation of information ${ }^{[8]}$ when their specific inherent limitations were taken into consideration. [7,9-11] Management decisionmaking and policy-making are the important parameters for the evaluation of water quality index factors. Through the experimental observations, it was identified that phosphate, nitrate, and solids are existed in the water ${ }^{[12]}$.

The demand for secondary minerals has been rising exponentially in the state of Kerala over the years to meet its ever increasing requirements towards the construction sector. Mining and quarrying are one of the critical areas of significance in the state of Kerala, which has low capita in land, lesser population density and available natural resources. Clay is the earliest and most comprehensive mineral resource used in the construction industry both as a building material and as a foundation structure. ${ }^{[13,14]}$ There are about 400 tile factories and 5,000 brick kilns spread over the entire state. ${ }^{[15]}$

The fast bound development and uncontrolled exploitation of natural resources lead to water and air pollution, which further limits freshwater availability. In Kerala, out of 1001 panchayats, only 300 are facilitated with the supply of safe and protected water; the remaining $70 \%$ depend on local water sources. People depend mainly on groundwater sources to satiate their domestic needs in these areas, and open dug wells serve as the major water extraction structure in the state. On an average, the density of these wells per sq. $\mathrm{Km}$ is 200 in the coastal belt, 150 in Midlands and 70 in the highlands. ${ }^{[16]}$ There are more than 44 rivers in Kerala; however, these rivers are considered to be polluted by untreated domestic water, agriculture and industrial wastes all flow into these water bodies. Also, most of the industries in Kerala are deemed to thickly populated by the riverside specifically near the towns and cities. In Kerala, there is a lack of proper water treatment system in city industries and municipalities ${ }^{[17]}$. It was found that there are various minerals and soil types in Kerala with different types of mineral deposits such as steatite, gemstones, lime shell, granite (dimension stone), magnesite, limestone, gold, bauxite, and so on.

This study has aimed to evaluate the clay mining effect on the chemical and physical characteristics of drinking water sources around the mining zone. The study area is found in the catchment of Kuppam- Payangadi, which is one of the west flowing rivers in Kerala in the sedimentary rock formation. The study has made use of physicochemical characteristics like $\mathrm{pH}$, colour, turbidity, total dissolved solids, total hardness, total alkalinity, chloride $(\mathrm{Cl})$, sulphate $\left(\mathrm{SO}_{4}\right)$, calcium $(\mathrm{Ca})$, magnesium $(\mathrm{Mg})$, iron $(\mathrm{Fe})$, sodium $(\mathrm{Na})$, potassium $(\mathrm{K})$, silica $\left(\mathrm{SiO}_{2}\right)$, chemical oxygen demand

\section{Volume 6 Issue 1, January 2017




\section{International Journal of Science and Research (IJSR) \\ ISSN (Online): 2319-7064}

Index Copernicus Value (2015): 78.96 | Impact Factor (2015): 6.391

(COD) in water during pre and post monsoon conditions. Our study is based on WHO specification and is by the APHA standards.

\section{Literature Review}

Various researchers conducted studies with regards to premonsoon and post-monsoon impacts, and this section provides an overall summary of the existing research work carried in the water management field of research. Sudhakar and Hemant ${ }^{[18]}$ studied the open well water quality in Varangaon region with the aid of physicochemical methods to assess the effect of pre-monsoon and post-monsoon impacts. The study findings revealed that the quality of drinking water during the pre-monsoon season is better than that of the post monsoon season. Also, the water source does not pose any harm to local inhabitants though the hardness level is higher than $200 \mathrm{mg} / \mathrm{l}$. In the same context, Gaur et al. ${ }^{[19]}$ aimed to determine the quality of water in 15 regions of Uttarakhand, India. These research findings revealed that heavy metals like $\mathrm{Al}, \mathrm{Pb}, \mathrm{Mn}, \mathrm{Cd}, \mathrm{Ba}, \mathrm{Co}, \mathrm{Cu}, \mathrm{Cr}$, and $\mathrm{Fe}$ were determined in the ground water samples using ICP mass spectroscopy. Further, this research revealed that the alkalinity is above the Bureau of Indian Standards (BIS) permissible level.

Thomas et al. ${ }^{[20]}$ also aimed to study the physicochemical parameters to assess the quality of potable water in the Eloor industrial area, Kerala. The study results revealed after comparing with the WHO guidelines IS: 10500, 1991 and $2006, \mathrm{pH}$, total hardness, concentration of iron, Zinc fluoride were not within the acceptable range. Chand ${ }^{[21]}$ reported a study on the quality of groundwater in the district of Palakkad, Kerala. The study findings revealed the presence of high fluoride content in Palghat district and the higher value is considered to be present in the samples from Kopanur (5.75 ppm). Murugan ${ }^{[22]}$ studied the quality of ground water in the district of Pathanamthitta, Kerala by 20 samples. The study findings revealed that there is a rise in the range of minerals in water during post monsoon period when compared to the pre-monsoon period. Yadav and Khan [23] analyzed the quality of ground water in Todaraisingh Tehsil Tonk district by considering north, east, south, the central part and west of Rajasthan, India. In this state, there are about 83,200 villages and habitations which suffer from fluoride issues. Also, the study revealed that fluoride content in this study ranged from $0.35 \mathrm{mg} / \mathrm{L}$ to $9 \mathrm{mg} / \mathrm{L}$.

Dohare et al. ${ }^{[24]}$ aimed at assessing the quality of ground water with the aid of physicochemical methods to mark the WQI for the ground water of Indore City and its nearby industrial area. The study findings reveal that most of the water quality parameters were slightly higher during the rainy season than in the dry season. Through the review it is observed that several authors have conducted bore well, open well studies in Kerala for each district during different seasons both physically and chemically. However, the present study is unique because the analysis of test parameters is based on WHO specification and is by the APHA standards.

\section{Physicochemical parameters of the APHA Standard}

In the year of 1872, APHA standard are developed by public health professionals of about 50,000 members and 77 public health occupations. This specification defined necessary Physicochemical Parameters to promote and protect the environmental and personal health ${ }^{[25]}$. As per, the standard potable water should contain only permissible limits of various physicochemical parameters. Water contains different kinds of dissolved, floating or solvent microbiological impurities. Hence, the testing of water before domestic, industrial and drinking purposes is critical. Analyses were performed for various physicochemical parameters. The selection of these parameters depends mainly on the purpose of usage, and also the purity and quality requirement. The testing may performed in two types namely physical and chemical. The former will test physical appearances such as color, temperature, smell, $\mathrm{pH}$, TDS, turbidity, and the latter is performed for testing dissolved oxygen, BOD, alkalinity, COD hardness and other parameters.

High purity water can obtained by testing traces of contents such as organic pesticide, heavy metals and so on. Therefore, drinking water must pass through all the above tests and should contain the necessary mineral content in permissible levels. It was found that physicochemical parameters were resolute using standard methods prescribed by APHA ${ }^{[26]}$ and ASTM International ${ }^{[27]}$. There exist different physicochemical parameters which they are frequently tested to monitor the water quality. ${ }^{[28]}$ such as temperature ${ }^{[29]}, \mathrm{pH}^{[30]}$, Carbon-Dioxide ${ }^{[31]}$, alkalinity ${ }^{[28]}$ carbonate [32], bicarbonate, total dissolved solids [33-35] chloride ${ }^{[36]}$ and total hardness ${ }^{[37]}$ in water.

\section{Materials and Methods}

Materials adopted for predicting the suitability of drinking water is based on APHA standard for analysis. This research uses Suitability Sites Occurrence Model (SSOM) for predicting the suitability of drinking water. To examine the impact of clay mining activity on drinking water the study area considered in this research are Payangadi, Kannur District in Kerala. The data collection adopted in the present study is quantitative methodology wherein water samples are collected from October 2014, and May 2015. The study has considered 15 samples from the wells WE1 to WE7 on the east side of the mining area and WW1 to WW7 on the west side and WM of the mining area in the current study during the pre-monsoon and post-monsoon period.

Study Parameters: In order evaluate the water capability for drinking purpose as per APHA standard composite of variables were measured. The physicochemical characteristics such as $\mathrm{pH}$, Colour, turbidity, TDS, total hardness, total alkalinity, $\mathrm{Cl}-\mathrm{SO}_{4}{ }^{2-}, \mathrm{Ca}, \mathrm{Mg}, \mathrm{Fe}, \mathrm{Na}, \mathrm{K}$, $\mathrm{SiO}_{2}$ and COD are considered for the present study and water samples are obtained during pre-monsoon and postmonsoon season 


\section{International Journal of Science and Research (IJSR) \\ ISSN (Online): 2319-7064}

Index Copernicus Value (2015): 78.96 | Impact Factor (2015): 6.391

\section{Results and Discussion}

Monitoring the water resources quantifies the water quality and density impairments, and policy makers make use of the land use decisions which does not include naturally preserved areas. To mitigate the effects of human society in the natural water sources, it is becoming progressively important to apply complete monitoring of water quality in these regions.

The present study has adopted APHA standard where Figure 1 represents the geographical location of study area. The monitored values of physicochemical parameters such as $\mathrm{pH}$, color, turbidity, total dissolved solid, total hardness, total alkalinity, chloride of Madai clay water samples are found. Those parameters are classified based on the wells WE1 to WE7 on the east side of the mining area and WW1 to WW7 on the west side and WM of the mining area ${ }^{[43,44]}$. Also, Figure 2 and Figure 3 represent the graphical representation of physicochemical parameters during the pre-monsoon and post-monsoon period. It is found that the mine sample has the higher value regarding total dissolved solids during both pre-monsoon and post-monsoon samples which are evident from figure 2 and figure 3 . Also, it is found that post-monsoon season has a gradual increase of mineral content in water than that of the pre-monsoon.

Test Results: The study has collected data from the October 2014 and May 2015. In this context, the study has considered 15 samples these are measured using the test methods such as APHA 2012 (Part 4500H+), APHA 2012 (Part 2120), APHA 2012 (Part 2130), APHA 2012 (Part 2540), APHA 2012 (Part 2340), APHA 2012 (Part 2320), APHA 2012 (Part $4500 \mathrm{Cl}$-), APHA 2012 (Part $4500 \mathrm{SO}_{4}{ }^{2-}$ ), APHA 2012 (Part $3500 \mathrm{Ca}$ ), APHA 2012 (Part $3500 \mathrm{Mg}$ ), APHA 2012 (Part 3500Fe), APHA 2012 (Part 3500 Na), APHA 2012 (Part 3500 K), APHA 2012 (Part 5220), APHA 2012 (Part $3500 \mathrm{Mn}$ ), APHA 2012 (Part $3500 \mathrm{~Pb}$ ) and APHA 2012 (Part $3500 \mathrm{Cd}$ ). The Table 1 presented below represents the parameters involved along with the test method.

Figure 4 represents the mining sample which uses the test parameters. From this figure, it is found that APHA 2012 (part 2540) has the higher test result. Figure 5 represents the mining sample utilizing the test parameters. It is found that APHA 2012 (part 2540) has the higher test result. From the figure 4 , it was found that total dissolved solvent has the highest test result after mining the sample during the months of May and April 2015.

Statistical Analysis: A paired samples t-test is used to compare two related means. It tests the null hypothesis that the difference between two related means is 0 . Table 2 represents the t-test values for the pre-monsoon and postmonsoon. It is found that when $p<0.05$, it indicates there exists a difference between pre-monsoon and post-monsoon effects of a specific characteristic whereas $p>0.05$ indicates no difference between pre-monsoon and post-monsoon season. The statistical significance value ( $p$-value) clearly reveals that pre and post monsoon effects do not pose changes in the $\mathrm{pH}$ color, total hardness, chloride, magnesium, iron, and silica of both east and west lying wells to the mining area. Whereas in the turbidity, total alkalinity, and total dissolved solids there is no difference on the east lying wells from the mine sample and there is a difference on the west lying wells from the mine sample in which higher significance value in the pre-monsoon season. In the case of sodium and COD, there is no difference on the west lying wells from the mine sample, and there exist a difference in the east lying wells from the mine sample in which higher significance value in the pre-monsoon season. However, there is a difference on the west lying wells and east lying wells from the mine sample in the case of sulphate, calcium, and potassium with the higher significance value in the pre-monsoon season. From this paired test it is found that pre-monsoon has the greater significance than that of the post-monsoon.

\section{Findings}

The current study has considered IS 10500:2012 and WHO 2012 standards to identify permissible limits of physicochemical parameters in water. The study has found that in the in selected water samples an average of $38.57 \%$ water are collected in pre-monsoon, and $61.53 \%$ of the samples are selected in post-monsoon as shown in Table 3 and Table 4 . In the pre-monsoon season, $20 \%$ of the water samples are found to be lying within the permissible limits stated for total hardness in water (IS-10500:2012) whereas only $13.33 \%$ of post-monsoon water samples are found to be lying within the permissible limits. The present study results revealed that the average of $86.66 \%$ of the water samples are found to be lying within the permissible limit stated for total alkalinity in water (IS-10500:2012). However, there is no difference between pre-monsoon and post-monsoon impact due to clay mining activity.

The $\mathrm{pH}$ value ranges between 2.5 to 6.3 in which is within the permissible limit stated for $\mathrm{pH}$ in water (IS-10500:2012) for both monsoons. The color value ranges from 0 to 18 which is $6.67 \%$ water limit stated for color in water (IS10500:2012). The turbidity value ranges from 0 to 25 in the pre-monsoon in which none of the water samples falls within the permissible limit stated for turbidity in water (IS10500:2012). However, in the post-monsoon the value ranges from 0.1 to 28 in which $6.67 \%$ of water samples found to be within the permissible stated for turbidity in water (IS-10500:2012). In the case of TDS, value ranges from 200 to 4500 in which $73.33 \%$ of water samples found to be within the permissible stated for TDS in water (IS$10500: 2012$ ) in pre-monsoon, and $86.67 \%$ of water samples found to be within the allowable stated for TDS in water in post-monsoon. The total hardness value ranges from 120 to 2900 in pre-monsoon and post-monsoon in which $20 \%$ of water samples found to be within the permissible stated of total hardness in water (IS-10500:2012) in pre-monsoon and $13.33 \%$ of water samples found to be within the allowable stated for total hardness.

Total alkalinity value ranges from 0 to 230 in pre-monsoon and post-monsoon in which $86.66 \%$ of water samples found to be within the permissible stated for total alkalinity in water (IS-10500:2012) in both pre-monsoon and postmonsoon. In chloride, the value ranges from 30 to 435 in the pre-monsoon and post-monsoon in which $73.33 \%$ of water

\section{Volume 6 Issue 1, January 2017}




\section{International Journal of Science and Research (IJSR) \\ ISSN (Online): 2319-7064}

Index Copernicus Value (2015): 78.96 | Impact Factor (2015): 6.391

samples found to be within the permissible stated for chloride in water (IS-10500:2012) in pre-monsoon, and $66.66 \%$ of water samples found to be within the permissible stated for chloride in water. The sulphate value ranges from 11 to 2800 in pre-monsoon and post-monsoon in which $33.33 \%$ of water samples found to be within the permissible stated for sulphate in water (IS-10500:2012) in both premonsoon and post-monsoon. The calcium value ranges from 30 to 900 in both pre-monsoon and post-monsoon in which $46.66 \%$ of water samples found to be within the permissible stated for calcium in water (IS-10500:2012). The magnesium value ranges from 10 to 200 in both premonsoon and post-monsoon in which $66.66 \%$ of water samples found to be within the permissible stated for magnesium in water (IS-10500:2012) whereas in premonsoon $60 \%$ of water samples found to be within the allowable limit stated for magnesium.

In the case of iron, the value ranges from 0 to 190 for both monsoons in which $13.33 \%$ of water samples found to be within the permissible stated of iron in water (IS10500:2012) in pre-monsoon and post-monsoon. The silica value ranges from 1.0 to 90 in both pre-monsoon and postmonsoon in which the $6.67 \%$ of water samples found to be within the permissible stated for silica in water (IS10500:2012). The COD value ranges from 35 to 250 of water samples found to be within the allowable stated for COD is water (IS-10500:2012) in both pre-monsoon and post-monsoon. However, the concentration of the potassium in drinking water is small. Even though a significant amount of emetic effect has found, the environment protection agency (EPA) does not found any maximum permissible limit ${ }^{[37]}$.

\section{Conclusion}

This study concentrated on quality assessment parameters of water with different parameters $\mathrm{pH}$, salinity, TDS and evaluated for acceptable limit based on WHO and IS10500:2012 drinking water quality standards. The findings of the study revealed that the quality of drinking water is considerably affected by clay mining activity for the average water sample level of $30.09 \%$ as per the IS-10500:2012 and WHO 2012. The evaluation of water samples is carried by considering monsoon impact on physiochemical parameters of water. The analyses results demonstrate that clay mining activity in particular region affects the quality of drinking water which makes unfit for drinking. The reason which makes water not suitable for drinking is due to clay mining activity mineral level get degrades in water. Among different minerals potassium content in water is drastically reduced which may lead to serious health impacts like hypokalaemia and other health hazards. Hence to make water suitable for drinking appropriate clay mining method need to be adopt by evaluating the clay level and sociological factors involved in the mining region. To overcome these issues pumping and diversion of water will be utilized to make water more suitable for drinking. Water diversion can be performed by directing the water area for living places or by storing the water by constructing dam for future applications.

\section{Future Scope}

Even though this research concentrates on clay mining activity of particular state alone, it provides a broader view of the impact of mining activity in drinking water. This research can be further enhanced by evaluating mining activity impact all over India and worldwide. Further in future, it may assessed by examining the socio-economic factors involved in the suitability of water due to mining activity.

\section{Acknowledgement}

We thank the service rendered by the Directors of National Centre for Earth Science Studies (NCESS), Aakulam, Thiruvanathapuram and Director, Centre for Water Resources Development and Management, Kunnamangalam (MBR) Kozhikode (CWRDM) for providing infrastructural facilities for analyzing the samples. Service rendered by Prof. P K Rajan, Adjunct Faculty in Geology in the Department of Civil Engineering, Government Engineering College, West Hill, Kozhikode in guiding in the field, is sincerely acknowledged.

\section{References}

[1] R.K. Horton, An index number system for rating water quality. J. Water Pollut. Control Fed. 1965,37,300-305.

[2] R.M. Brown, N.I. McClelland, R.A. Deininger, R.G Tozer, A water quality index-do we dare? Water Sew. Works 1970,117,339-343.

[3] W.R. Ott, Environmental Indices: Theory and Practice. 1978 (Ann Arbor Science Publisher Inc.,: Ann Arbor, Michigan)

[4] W.W. Miller, H.M. Joung, C.N. Mahannah, J.R. Garret, Identification of Water Quality Differences in Nevada Through Index Application1. J. Environ. Qual. 1986, 15,265

[5] A.A. Bordalo, W. Nilsumranchit, K. Chalermwat, Water quality and uses of the Bangpakong River (Eastern Thailand). Water Res. 2001,35,3635-3642.

[6] C.G. Cude, Oregon Water Quality Index: A Tool for Evaluating Water Quality Management Effectiveness. $J$. Am. Water Resour. Assoc. 2001,37,125-137.

[7] D. Hallock, in: Environment assessment program 2002, pp. 1-23 (Olympia, WA).

[8] N. Stambuck-Giljanovic, Water quality evaluation by index in Dalmatia. Water Res. 1999,33,3426-3440.

[9] W.R. Otto, Environmental Indices: Theory and Practice. 1978 (Ann Arbor Science Publisher Inc.: Ann Arbor, Michigan)

[10] J.C. Flores, Comments to the use of water quality indices to verify the impact of Córdoba City (Argentina) on Suquía river. Water Res. 2002,36,4664-4666.

[11] S.F. Pesce, D.A. Wunderlin, Reply to comment on 'Use of water quality indices to verify the impact of Cordoba city (Argentina) on Suquia River'. Water Res. 2002,36,4990-4991.

[12] Water Quality Tests Summary. ,13-23.

[13] J.E. Gillott, Clay Mineralogy in Building Research*. Clays Clay Miner. 1962,11,296-298.

[14] I. Johari, S. Said, R.P. Jaya, B.H.A. Bakar, Z.A. Ahmad, 


\section{International Journal of Science and Research (IJSR) \\ ISSN (Online): 2319-7064 \\ Index Copernicus Value (2015): 78.96 | Impact Factor (2015): 6.391}

in: 2011 International Conference on Environment Science and Engineering IPCBEE vol.8 (2011) 2011, pp. 171-174 (IACSIT Press: Singapore).

[15] State Planning Board, Ninth Five-Year Plan 1997-2002. Report of the task force on mining. 1996 (State Planning Board, Government of Kerala: Thiruvananthapuram, Kerala)

[16]CWRDM, Water Atlas of Kerala. 1995 (Centre for Water Resources. Development and Management: Kunnamangalam, Kozhikode)

[17] Meanausa, Kerala Water Resource - Threats And Management Issues. meanausa.org2016,

[18] M.P. Sudhakar, M.A. Hemant, Physico-Chemical Analysis of Drinking Ground Water in Varangaon Region, Dist Jalgaon, Maharashtra, India. Res. J. Chem. Sci. 2008,3,83-85.

[19]A. Gaur, V. Kumar, R. Sarathy, in: Advances In International Management - Dynamics of Globalization: Location-Specific Advantages Or Liabilities of Foreignness? (Eds T. Asmussen, M. Devinney, T. Pedersen, L. Tihanyi) 2011, (Emerald: New York, NY).

[20]D.R. Thomas, B. Sunil, C. Latha, Physico- Chemical Analysis of Well Water at Eloor Industrial AreaSeasonal Study. Curr. World Environ. 2011,6,259-264.

[21]A. Chand, Ground Water Information Booklet Of Palakkad District, Kerala State. 2013 (Kerala)

[22] S. Murugan, Ground Water Information Booklet Of Pathanamthitta District, Kerala State. 2013 (Kerala)

[23]A.K. Yadav, P. Khan, A Comparative Study of Premonsoon and Postmonsoon Status of Different Physical and Chemical Parameters of Water Samples Collected from the Various Sources of Water in Todaraisingh Tehsil of Tonk (Rajasthan) India. Glob. J. Sci. Front. Res. Environ. Earth Sci. 2013,13,23-32.

[24] D. Dohare, S. Deshpande, A. Kotiya, Analysis of Ground Water Quality Parameters: A Review. Res. J. Eng. Sci. 2014,3,26-31.

[25] American Public Health Association, Standard Methods for the Examination of Water and Wastewater. 8th ed. 1992 (American Public Health Association: Washingdon, DC)

[26] APHA, Standard Methods For Examination of Water and Wastewater. 20th ed. 1985 (American Public Health Association: Washington D. C.)

[27] ASTM International, Annual Book of ASTM Standards, Water and Environmental Technology v. 11.01. 2003 (Pennsylvania: West Conshohocken)

[28]P.N. Deshmukh, D. V Patil, R.N. Sawant, Physicochemical parameters for testing of water - A review. Int. J. Environ. Sci. 2012,3,1194-1207.

[29] M. Prasad, B.M. Reddy, M.R. Reddy, V. Sunitha, Studies on physicochemical parameters to assess the water quality in Obulavaripalli Mandal of YSR (Kadapa) District, Andhra Pradesh, India. Int. J. Curr. Res. Acad. Rev. 2014,2,31-41.

[30]D.P. Gupta, D.. Sunita, J.P. Saharan, Physiochemical
Analysis of Ground Water of Selected Area of Kaithal City (Haryana) India. Researcher 2009,1,1-5.

[31] Water Quality Control: Part II. Parameters of Water. ,39-85.

[32] A.K. Dixit, S.K. Pandey, R. Mehta, Niyaz Ahmad, Gunjan, JyotiPandey, Study of physico-chemical parameters of different pond water of Bilaspur District, Chhattishgarh, India. Environ. Skept. Critics, 2015,4,89-95.

[33] K. Rao, M. Karthikeyan, P. Sukumaran, Limnology and fish yield enhancement Reservoir (Cauvery River System). J. Inl. Fish. Soc. India 2003,3,20-27.

[34]A. Kirubavathy, Binukumari S, N. Mariamma, T. Rajammal, Assessement of water quality of Orthupalayam reservoir, Erode District, Tamil Nadu. $J$. Ecophysiol. Occup. Heal. 2005,53-54.

[35] R. Garg, D. Saksena, R. Rao, Assessment of physicochemical water quality of Harsi Reservoir, district Gwalior, Madhya Pradesh. J. Ecophysiol. Occup. Heal. 2006,6,33-40.

[36] R. Rajendran, A.P. Rajan, A.S. Raja, V. Prathipa, M.S. Dheenadayalan, Assessment of Physico-Chemical Parameters of River Cauvery In and Around Nerur. $J$. Environ. Sci. Pollut. Res. 2015,1,17-19.

[37]T. Scherer, Drinking Water Quality: Testing and Interpreting Your Results [Internet]. 2015Available from:

https://www.ag.ndsu.edu/pubs/h2oqual/watsys/wq1341. pdf

[38] S. Pawar, R. Vaidya, in: Proceeding of International Conference SWRDM-2012 2012, pp. 129-131 (Department of Environmental Science: Kolhapur).

[39]P.C. Sujitha, D. Mitra Dev, P.K. Sowmya, R. Mini Priya, Physico-chemical parameters of Karamana river water in Trivandrum district, Kerala, India. Agris Online Pap. Econ. Informatics 2012,2,1417-1434.

[40] S. Thomas, M. Harindranathan Nair, Isb. Singh, Physicochemical Analysis of Seafood Processing Effluents in Aroor Gramapanchayath, Kerala. IOSR J. Environ. Sci. Ver. III 2015,9,2319-2399.

[41] A.J.A. Ashok, R. John, A. Mathew, R. Raghunath, A.M.S. Nair, Study of Physicochemical Parameters in Selected Ponds of Athiyannoor Block Panchayat, Kerala. emergent Life Sci. Res. 2015,1,47-52.

[42] N.K. Amaliya, S.P. Kumar, Emphasizing the Quality of Some Selected Ground Water Samples of Kanyakumari District, India Using Quality Index Assessment. Int. Res. J. Environ. Sci. 2013,2,76-82.

[43] S. Shrestha, F. Kazama, Assessment of surface water quality using multivariate statistical techniques: A case study of the Fuji river basin, Japan. Environ. Model. Softw. 2007,22,464-475.

[44]A.B. Mukherjee, P. Bhattacharya, A. Sarkar, R. Zevenhoven, in: Mercury Fate and Transport in the Global Atmosphere: Emissions, Measurements and Models 2009, pp. 81-112 (Springer: New York, USA). 
International Journal of Science and Research (IJSR)

ISSN (Online): 2319-7064

Index Copernicus Value (2015): 78.96 | Impact Factor (2015): 6.391

Tables and Figures

\section{List of Tables}

Table 1: Parameters and their test method

\begin{tabular}{|c|c|}
\hline Test method & Parameters \\
\hline APHA 2012 (Part 4500H+) & $\mathrm{pH}$ \\
\hline APHA 2012 (Part 2120) & Colour, Hazen \\
\hline APHA 2012 (Part 2130) & Turbidity, NTU \\
\hline APHA 2012 (Part 2540) & Total dissolved solids(TDS), $\mathrm{mg} / \mathrm{l}$ \\
\hline APHA 2012 (Part 2340) & Total hardness, mg/l \\
\hline APHA 2012 (Part 2320) & Total alkalinity, mg/l \\
\hline APHA 2012 (Part 4500 Cl-) & Chloride(Cl-), mg/l \\
\hline APHA $2012\left(\right.$ Part $\left.4500 \mathrm{SO}_{4}{ }^{2-}\right)$ & Sulphate $\left(\mathrm{SO}_{4}{ }^{2-}\right), \mathrm{mg} / \mathrm{l}$ \\
\hline APHA 2012 (Part 3500Ca) & Calcium(Ca), mg/l \\
\hline APHA 2012 (Part 3500Mg) & Magnesium(Mg), mg/l \\
\hline APHA 2012 (Part 3500Fe) & Iron $(\mathrm{Fe}), \mathrm{mg} / \mathrm{l}$ \\
\hline APHA 2012 (Part $3500 \mathrm{Na})$ & Sodium(Na), mg/l \\
\hline \multirow[t]{2}{*}{ APHA 2012 (Part 3500K) } & Potassium, mg/l \\
\hline & Silica (SiO2),mg/l \\
\hline APHA 2012 (Part 5220) & $\mathrm{COD}, \mathrm{mg} / \mathrm{l}$ \\
\hline APHA 2012 (Part 3500Mn) & Manganese $(\mathrm{Mg}) \mathrm{mg} / 1$ \\
\hline APHA 2012 (Part 3500Pb) & Lead $(\mathrm{Pb}), \mathrm{mg} / \mathrm{l}$ \\
\hline APHA 2012 (Part 3500Cd) & Cadmium(Cd), mg/l \\
\hline
\end{tabular}

Table 2: Statistical analysis of water quality characteristics

\begin{tabular}{|c|c|c|c|c|c|}
\hline \multirow[t]{2}{*}{$\mathrm{p}$-value } & \multirow[t]{2}{*}{ t-value } & Post-monsoon & Pre-monsoon & \multirow[t]{2}{*}{ Location } & \multirow[t]{2}{*}{ Variables } \\
\hline & & \multicolumn{2}{|c|}{ Mean \pm SD } & & \\
\hline .583 & -.581 & $4.36 \pm 1.35$ & $4.27 \pm 1.36$ & Well-east & \multirow[t]{2}{*}{$\mathrm{PH}$} \\
\hline .138 & 1.710 & $4.69 \pm 1.72$ & $4.84 \pm 1.57$ & Well-west & \\
\hline .071 & -2.193 & $1.1670 \pm 1.05484$ & $.8486 \pm 1.06074$ & Well-east & \multirow[t]{2}{*}{ Colour,Hazen } \\
\hline .645 & -.486 & $.1649 \pm .03974$ & $.1531 \pm .04489$ & Well-west & \\
\hline .184 & -1.503 & $6.1121 \pm 3.36287$ & $5.4586 \pm 3.72364$ & Well-east & \multirow[t]{2}{*}{ Turbidity, NTU } \\
\hline .030 & -2.842 & $3.8620 \pm 4.10985$ & $3.5605 \pm 4.12167$ & Well-west & \\
\hline .120 & -1.811 & $1073.7471 \pm 412.43937$ & $937.9048 \pm 320.89509$ & Well-east & \multirow{2}{*}{$\begin{array}{l}\text { Total dissolved } \\
\text { solids, mg/l }\end{array}$} \\
\hline .011 & -3.617 & $723.5071 \pm 405.29956$ & $672.1429 \pm 392.63501$ & Well-west & \\
\hline .142 & -1.692 & $425.7179 \pm 148.34782$ & $411.6190 \pm 141.39051$ & Well-east & \multirow{2}{*}{$\begin{array}{c}\text { Total hardness, } \\
\mathrm{mg} / \mathrm{l}\end{array}$} \\
\hline .787 & -.282 & $249.7450 \pm 153.67194$ & $247.8571 \pm 169.39859$ & Well-west & \\
\hline .700 & -.404 & $94.4497 \pm 99.94036$ & $93.4538 \pm 97.72267$ & Well-east & \multirow{2}{*}{$\begin{array}{c}\text { Total alkalinity, } \\
\mathrm{mg} / \mathrm{l}\end{array}$} \\
\hline .026 & -2.951 & $66.7816 \pm 61.08062$ & $64.7062 \pm 60.22392$ & Well-west & \\
\hline .287 & -1.169 & $174.0568 \pm 143.18406$ & $164.2357 \pm 144.85667$ & Well-east & \multirow[t]{2}{*}{ Chloride, $\mathrm{mg} / \mathrm{l}$} \\
\hline .099 & -1.951 & $170.8898 \pm 127.40233$ & $166.3082 \pm 129.81855$ & Well-west & \\
\hline .024 & -3.000 & $313.4975 \pm 257.08805$ & $305.0244 \pm 252.58081$ & Well-east & \multirow[t]{2}{*}{ Sulphate, mg/l } \\
\hline .001 & -5.580 & $279.4102 \pm 238.67466$ & $275.3023 \pm 238.00250$ & Well-west & \\
\hline .002 & -5.341 & $89.4079 \pm 57.38743$ & $87.4747 \pm 57.08906$ & Well-east & \multirow{2}{*}{ Calcium, mg/l } \\
\hline .040 & -2.613 & $91.1136 \pm 62.23152$ & $88.9246 \pm 60.23177$ & Well-west & \\
\hline .059 & -2.320 & $25.1621 \pm 11.75244$ & $23.7606 \pm 11.63283$ & Well-east & \multirow{2}{*}{$\begin{array}{c}\text { Magnesium, } \\
\mathrm{mg} / \mathrm{l}\end{array}$} \\
\hline .392 & -.922 & $25.8217 \pm 11.22825$ & $25.3398 \pm 11.04308$ & Well-west & \\
\hline .189 & 1.482 & $21.4522 \pm 16.72520$ & $22.0606 \pm 17.29285$ & Well-east & \multirow[t]{2}{*}{ Iron, mg/l } \\
\hline .327 & 1.066 & $25.6255 \pm 20.80350$ & $25.9510 \pm 21.36627$ & Well-west & \\
\hline .005 & -4.253 & $24.6646 \pm 14.15874$ & $22.1203 \pm 12.79477$ & Well-east & \multirow[t]{2}{*}{ Sodium, mg/l } \\
\hline .220 & -1.368 & $23.5772 \pm 8.72633$ & $23.0868 \pm 8.79299$ & Well-west & \\
\hline .036 & -2.682 & $8.0623 \pm 3.72946$ & $7.5151 \pm 3.37135$ & Well-east & \multirow{2}{*}{$\begin{array}{c}\text { Potassium, } \\
\mathrm{mg} / 1\end{array}$} \\
\hline .025 & -2.973 & $7.5648 \pm 3.98507$ & $6.7688 \pm 3.86409$ & Well-west & \\
\hline .052 & -2.418 & $37.6138 \pm 31.06338$ & $35.4452 \pm 30.16704$ & Well-east & \multirow{2}{*}{$\begin{array}{c}\text { Silica } \\
(\mathrm{SiO} 2), \mathrm{mg} / 1\end{array}$} \\
\hline .097 & -1.962 & $28.8138 \pm 29.56967$ & $27.7633 \pm 28.37859$ & Well-west & \\
\hline .007 & -3.960 & $159.3421 \pm 95.55701$ & $154.6190 \pm 97.44940$ & Well-east & \multirow[t]{2}{*}{$\mathrm{COD}, \mathrm{mg} / \mathrm{l}$} \\
\hline .513 & -.694 & $156.2150 \pm 86.99851$ & $153.1905 \pm 83.76441$ & Well-west & \\
\hline
\end{tabular}

Volume 6 Issue 1, January 2017 www.ijsr.net 


\section{International Journal of Science and Research (IJSR) \\ ISSN (Online): 2319-7064}

Index Copernicus Value (2015): 78.96 | Impact Factor (2015): 6.391

Table 3: Physicochemical parameters range (October 2014)

\begin{tabular}{|c|c|c|c|c|c|c|c|c|c|c|c|c|c|c|c|c|}
\hline $\begin{array}{c}\mathrm{COD}, \\
\mathrm{mg} / \mathrm{l}\end{array}$ & $\begin{array}{c}\text { Silica } \\
(\mathrm{SiO} 2) \\
\mathrm{mg} / \mathrm{l}\end{array}$ & $\begin{array}{c}\text { Potassi } \\
\text { um, } \\
\mathrm{mg} / \mathrm{l}\end{array}$ & $\begin{array}{c}\text { Sodiu } \\
\text { m, } \\
\mathrm{mg} / \mathrm{l}\end{array}$ & $\begin{array}{l}\text { Iron, } \\
\mathrm{mg} / 1\end{array}$ & $\begin{array}{c}\text { Magnes } \\
\text { ium, } \\
\mathrm{mg} / \mathrm{l}\end{array}$ & $\begin{array}{c}\text { Calci } \\
\text { um, } \\
\mathrm{mg} / \mathrm{l}\end{array}$ & $\begin{array}{l}\text { Sulph } \\
\text { ate, } \\
\mathrm{mg} / \mathrm{l}\end{array}$ & $\begin{array}{c}\text { Chloride } \\
\text {, mg/l }\end{array}$ & \begin{tabular}{|c} 
Total \\
alkalinit \\
$\mathrm{y}$
\end{tabular} & $\begin{array}{c}\text { Total } \\
\text { hardness }\end{array}$ & TDS & $\begin{array}{c}\text { Turbidit } \\
\mathrm{y}\end{array}$ & Color & $\mathrm{pH}$ & $\begin{array}{c}\text { APH } \\
\text { A } \\
\text { RAN } \\
\text { GE } \\
\end{array}$ & $\begin{array}{c}\text { Variabl } \\
\text { es }\end{array}$ \\
\hline $\begin{array}{r}39.666 \\
66667 \\
\end{array}$ & \begin{tabular}{|c|}
1.33333 \\
3333 \\
\end{tabular} & \begin{tabular}{|c|}
3.034 \\
75 \\
\end{tabular} & $\begin{array}{c}5.482 \\
45 \\
\end{array}$ & 0 & 8.6963 & $\begin{array}{c}35.02 \\
4 \\
\end{array}$ & $\begin{array}{c}12.41 \\
76 \\
\end{array}$ & \begin{tabular}{|c|}
30.0191 \\
5 \\
\end{tabular} & 0 & \begin{tabular}{|c|}
128.666 \\
6667 \\
\end{tabular} & $\begin{array}{c}224.333 \\
3333 \\
\end{array}$ & 0 & 0 & \begin{tabular}{|l}
2.53333 \\
3333 \\
\end{tabular} & $\begin{array}{l}6.5- \\
8.5 .\end{array}$ & $\mathrm{pH}$ \\
\hline 40 & 6.14 & \begin{tabular}{|c|}
3.034 \\
75 \\
\end{tabular} & $\begin{array}{c}8.795 \\
8 \\
\end{array}$ & 0 & 6963 & $\begin{array}{c}36.61 \\
6 \\
\end{array}$ & $\begin{array}{c}19.70 \\
1\end{array}$ & \begin{tabular}{|c|}
36.2533 \\
3333 \\
\end{tabular} & 0 & $\begin{array}{c}136.333 \\
3333 \\
\end{array}$ & $\begin{array}{c}438.333 \\
3333\end{array}$ & 0 & \begin{tabular}{|c|}
.10333 \\
3333 \\
\end{tabular} & 36 & $\begin{array}{l}5.0- \\
15.0\end{array}$ & Color \\
\hline $\begin{array}{l}63.666 \\
66667 \\
\end{array}$ & $\begin{array}{l}.54333 \\
3333 \\
\end{array}$ & \begin{tabular}{|c|}
3.283 \\
5 \\
\end{tabular} & $\begin{array}{c}14.20 \\
86 \\
\end{array}$ & $\begin{array}{c}3.482 \\
5 \\
\end{array}$ & $\begin{array}{c}1.601 \\
7 \\
\end{array}$ & $\begin{array}{c}42.98 \\
4 \\
\end{array}$ & $\begin{array}{c}36.61 \\
6 \\
\end{array}$ & \begin{tabular}{|c|}
56.5266 \\
6667 \\
\end{tabular} & 0 & \begin{tabular}{|c|}
192.333 \\
3333 \\
\end{tabular} & 488 & 0.25 & \begin{tabular}{|c|}
0.12333 \\
3333 \\
\end{tabular} & 2.98 & $\begin{array}{c}1.0- \\
1.5 \\
\end{array}$ & $\begin{array}{c}\text { Turbidi } \\
\text { ty }\end{array}$ \\
\hline 81 & $\begin{array}{l}33 \\
3 \\
\end{array}$ & $\begin{array}{c}4.119 \\
3 \\
\end{array}$ & $\begin{array}{c}15.50 \\
21 \\
\end{array}$ & $\begin{array}{c}4.079 \\
5 \\
\end{array}$ & $\begin{array}{c}7.402 \\
55 \\
\end{array}$ & $\begin{array}{c}4.57 \\
6 \\
\end{array}$ & $\begin{array}{c}41.98 \\
9 \\
\end{array}$ & $\begin{array}{l}33 \\
3 \\
\end{array}$ & 0 & & $\begin{array}{r}500 \\
33 \\
\end{array}$ & & $\begin{array}{l}.14333 \\
3333 \\
\end{array}$ & $\begin{array}{r}3.05 \\
66 \\
\end{array}$ & $\begin{array}{c}500- \\
2 \\
000 \\
\end{array}$ & TDS \\
\hline $\begin{array}{l}88.333 \\
33333 \\
\end{array}$ & $\begin{array}{l}5.86333 \\
3333 \\
\end{array}$ & $\begin{array}{c}4.865 \\
55 \\
\end{array}$ & $\begin{array}{c}17.14 \\
385\end{array}$ & $\begin{array}{c}11.84 \\
05\end{array}$ & $\begin{array}{l}9.840 \\
3 \\
\end{array}$ & $\begin{array}{c}6.16 \\
8 \\
\end{array}$ & $\begin{array}{c}191.1 \\
594 \\
\end{array}$ & 65.1924 & \begin{tabular}{|c|c|}
11.2533 \\
3333 \\
\end{tabular} & 212 & & & $\begin{array}{c}0.14666 \\
6667 \\
\end{array}$ & \begin{tabular}{|c|}
3.10666 \\
6667 \\
\end{tabular} & 300 & $\begin{array}{c}\text { Total } \\
\text { hardnes } \\
\mathrm{S} \\
\end{array}$ \\
\hline & $\begin{array}{l}66 \\
7 \\
\end{array}$ & 5.174 & $\begin{array}{c}19.56 \\
17 \\
\end{array}$ & $\begin{array}{c}19.50 \\
2 \\
\end{array}$ & $\begin{array}{c}0.307 \\
95 \\
\end{array}$ & $\begin{array}{c}49.35 \\
2 \\
\end{array}$ & $\begin{array}{c}202.1 \\
84 \\
\end{array}$ & \begin{tabular}{|c|}
72.3464 \\
5 \\
\end{tabular} & $\begin{array}{r}11.5 \\
66 \\
\end{array}$ & $\begin{array}{l}33 \\
3 \\
\end{array}$ & 5 & 0.82 & & 3.23 & 120 & $\begin{array}{c}\text { Total } \\
\text { alkalini } \\
\text { ty }\end{array}$ \\
\hline $\begin{array}{l}119.66 \\
66667 \\
\end{array}$ & 9.36 & \begin{tabular}{|c|}
5.621 \\
75 \\
\end{tabular} & $\begin{array}{c}19.56 \\
17 \\
\end{array}$ & $\begin{array}{c}21.06 \\
415 \\
\end{array}$ & $\begin{array}{c}24.178 \\
5\end{array}$ & \begin{tabular}{|c|}
62.08 \\
8 \\
\end{tabular} & $\begin{array}{c}219.6 \\
96 \\
\end{array}$ & \begin{tabular}{|c|}
115.569 \\
25 \\
\end{tabular} & 506 & 240 & 561 & 6. & $\begin{array}{c}0.16333 \\
3333 \\
\end{array}$ & \begin{tabular}{|c|}
3.58666 \\
6667 \\
\end{tabular} & 250 & $\begin{array}{l}\text { Chlorid } \\
\text { e, mg/l }\end{array}$ \\
\hline $\begin{array}{l}136.33 \\
33333 \\
\end{array}$ & 2 & $\begin{array}{c}6.895 \\
35 \\
\end{array}$ & $\begin{array}{c}22.00 \\
94 \\
\end{array}$ & $\begin{array}{c}27.16 \\
35\end{array}$ & \begin{tabular}{|c|}
25.143 \\
65 \\
\end{tabular} & \begin{tabular}{|c|}
78.00 \\
8 \\
\end{tabular} & $\begin{array}{c}318.4 \\
995 \\
\end{array}$ & \begin{tabular}{|c|}
116.976 \\
6667 \\
\end{tabular} & 5 & \begin{tabular}{|c|}
289.333 \\
3333 \\
\end{tabular} & $\begin{array}{c}858.666 \\
6667 \\
\end{array}$ & $\begin{array}{c}6.73333 \\
3333 \\
\end{array}$ & $\begin{array}{c}0.20666 \\
6667 \\
\end{array}$ & 3.8 & 200 & $\begin{array}{l}\text { Sulphat } \\
\text { e, mg/l }\end{array}$ \\
\hline $\begin{array}{l}136.66 \\
66667 \\
\end{array}$ & $\begin{array}{c}33.4666 \\
6667 \\
\end{array}$ & \begin{tabular}{|c|}
8.417 \\
7 \\
\end{tabular} & $\begin{array}{l}2.46 \\
71\end{array}$ & $\begin{array}{c}29.35 \\
25 \\
\end{array}$ & $\begin{array}{c}6.188 \\
4 \\
\end{array}$ & $\begin{array}{c}83.77 \\
9 \\
\end{array}$ & $\begin{array}{c}319.1 \\
96 \\
\end{array}$ & \begin{tabular}{|c|}
162.396 \\
6667 \\
\end{tabular} & 58.24 & 325 & 1122 & \begin{tabular}{|c|}
6.97333 \\
3333 \\
\end{tabular} & $\begin{array}{c}0.22333 \\
3333 \\
\end{array}$ & 5.03 & 75 & $\begin{array}{c}\text { Calciu } \\
\mathrm{m}, \mathrm{mg} / \mathrm{l}\end{array}$ \\
\hline & & $\begin{array}{c}8.656 \\
5 \\
\end{array}$ & $\begin{array}{c}26.71 \\
575 \\
\end{array}$ & $\begin{array}{c}32.23 \\
8 \\
\end{array}$ & $\begin{array}{l}9.014 \\
2 \\
\end{array}$ & $\begin{array}{c}0.34 \\
6 \\
\end{array}$ & $\begin{array}{c}388.8 \\
46 \\
\end{array}$ & $\begin{array}{c}220.796 \\
6667 \\
\end{array}$ & \begin{tabular}{|c|}
58.2766 \\
6667 \\
\end{tabular} & $\begin{array}{c}441.666 \\
6667 \\
\end{array}$ & & & & 16 & 30 & $\begin{array}{c}\text { Magnes } \\
\text { ium, } \\
\mathrm{mg} / \mathrm{l} \\
\end{array}$ \\
\hline \begin{tabular}{|l|}
248.33 \\
33333 \\
\end{tabular} & 44 & $\begin{array}{c}10.65 \\
645 \\
\end{array}$ & $\begin{array}{c}1.24 \\
3 \\
\end{array}$ & $\begin{array}{c}34.52 \\
65 \\
\end{array}$ & \begin{tabular}{|l|}
5.780 \\
2 \\
\end{tabular} & \begin{tabular}{|c|}
135.3 \\
2 \\
\end{tabular} & $\begin{array}{c}411.9 \\
3 \\
\end{array}$ & \begin{tabular}{|c|}
243.954 \\
1 \\
\end{tabular} & 66 & \begin{tabular}{|c|}
470.666 \\
6667 \\
\end{tabular} & $\begin{array}{c}1139.33 \\
3333 \\
\end{array}$ & $\begin{array}{c}8.03333 \\
3333 \\
\end{array}$ & .25 & 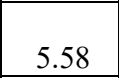 & 0.3 & $\begin{array}{l}\text { Iron, } \\
\mathrm{mg} / \mathrm{l}\end{array}$ \\
\hline $\begin{array}{l}248.66 \\
66667 \\
\end{array}$ & \begin{tabular}{|c|}
51.1666 \\
6667 \\
\end{tabular} & \begin{tabular}{|c|}
11.14 \\
4 \\
\end{tabular} & $\begin{array}{c}37.23 \\
29 \\
\end{array}$ & $\begin{array}{c}47.46 \\
15 \\
\end{array}$ & \begin{tabular}{|c|}
35.979 \\
2 \\
\end{tabular} & \begin{tabular}{|c|}
140.4 \\
94 \\
\end{tabular} & $\begin{array}{c}455.7 \\
1 \\
\end{array}$ & \begin{tabular}{|c|}
278.063 \\
3333 \\
\end{tabular} & \begin{tabular}{|c|}
148.343 \\
3333 \\
\end{tabular} & \begin{tabular}{|c|}
488.666 \\
6667 \\
\end{tabular} & $\begin{array}{c}1153.33 \\
3333 \\
\end{array}$ & $\begin{array}{c}8.13333 \\
3333 \\
\end{array}$ & $\begin{array}{c}0.92666 \\
6667 \\
\end{array}$ & 6.2 & 20 & $\begin{array}{c}\begin{array}{c}\text { Sodium } \\
\text { mg/l }\end{array} \\
\end{array}$ \\
\hline 251 & \begin{tabular}{|c|}
55.3166 \\
6667 \\
\end{tabular} & $\begin{array}{c}11.24 \\
35 \\
\end{array}$ & $\begin{array}{c}38.11 \\
845 \\
\end{array}$ & $\begin{array}{c}49.05 \\
35 \\
\end{array}$ & $\begin{array}{c}8.685 \\
6 \\
\end{array}$ & $\begin{array}{c}191.0 \\
4\end{array}$ & $\begin{array}{c}712.4 \\
2 \\
\end{array}$ & 283.86 & \begin{tabular}{|c|}
163.906 \\
6667 \\
\end{tabular} & 621 & $\begin{array}{c}1280.33 \\
3333 \\
\end{array}$ & $\begin{array}{c}9.03333 \\
3333 \\
\end{array}$ & $\begin{array}{c}1.33333 \\
3333 \\
\end{array}$ & 6.31 & 0 & $\begin{array}{c}\text { Potassi } \\
\text { um, } \\
\mathrm{mg} / 1\end{array}$ \\
\hline $\begin{array}{l}264.66 \\
66667\end{array}$ & $\begin{array}{c}79.4566 \\
6667\end{array}$ & $\begin{array}{c}12.17 \\
88\end{array}$ & $\begin{array}{c}8.40 \\
7\end{array}$ & $\begin{array}{c}56.31 \\
7 \\
\end{array}$ & 2.188 & 99 & $\begin{array}{c}731.9 \\
22\end{array}$ & $\begin{array}{c}376.373 \\
3333\end{array}$ & $\begin{array}{c}207.666 \\
6667 \\
\end{array}$ & $\begin{array}{c}640.666 \\
6667 \\
\end{array}$ & $\begin{array}{c}1311.33 \\
3333\end{array}$ & $\begin{array}{c}9.16666 \\
6667\end{array}$ & 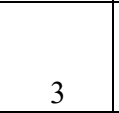 & 0.02 & 2 & $\begin{array}{c}\text { Silica } \\
(\mathrm{SiO} 2), \\
\mathrm{mg} / \mathrm{l}\end{array}$ \\
\hline 279 & \begin{tabular}{|c|}
85.2666 \\
6667 \\
\end{tabular} & $\begin{array}{c}12.80 \\
565 \\
\end{array}$ & 41.79 & $\begin{array}{c}189.0 \\
5\end{array}$ & \begin{tabular}{|l|}
193.03 \\
\end{tabular} & 796 & $\begin{array}{c}2686 . \\
5\end{array}$ & 434.26 & \begin{tabular}{|c|}
224.666 \\
6667 \\
\end{tabular} & \begin{tabular}{|c|}
2793.33 \\
3333 \\
\end{tabular} & 4469 & $\begin{array}{c}25.3333 \\
3333 \\
\end{array}$ & $\begin{array}{c}18.3333 \\
3333 \\
\end{array}$ & \begin{tabular}{|c|}
6.34333 \\
3333 \\
\end{tabular} & 0 & $\begin{array}{c}\mathrm{COD}, \\
\mathrm{mg} / 1\end{array}$ \\
\hline
\end{tabular}

Table 4: Physicochemical parameters range (May 2014)

\begin{tabular}{|c|c|c|c|c|c|c|c|c|c|c|c|c|c|c|c|c|}
\hline $\begin{array}{c}\mathrm{COD}, \\
\mathrm{mg} / \mathrm{l}\end{array}$ & $\begin{array}{l}\text { lica } \\
\mathrm{O} 2, \\
\mathrm{~g} / \mathrm{l}\end{array}$ & Pot & \begin{tabular}{|c|} 
Sodiu \\
$\mathrm{m}$, \\
$\mathrm{mg} / \mathrm{l}$ \\
\end{tabular} & & & & & ide & $\begin{array}{c}\text { Total } \\
\text { alkalinit } \\
\mathrm{y}\end{array}$ & \begin{tabular}{|c|} 
Total \\
hardnes \\
$\mathrm{s}$ \\
\end{tabular} & S & $\begin{array}{l}\text { urbidi } \\
\text { ty }\end{array}$ & Color & PII & $\begin{array}{c}\text { APHA } \\
\text { RANG } \\
\text { E }\end{array}$ & \\
\hline $\begin{array}{c}0.79 \\
5\end{array}$ & 592 & & $\begin{array}{c}6.666 \\
5\end{array}$ & 0 & & $\begin{array}{l}6.914 \\
5\end{array}$ & 16.526 & & 0 & 34 & & 99 & $\begin{array}{c}0.119 \\
4\end{array}$ & 66 & $\begin{array}{l}6.5- \\
8.5 \text {. }\end{array}$ & \\
\hline $\begin{array}{c}6.76 \\
5 \\
\end{array}$ & $\begin{array}{c}.671 \\
5 \\
\end{array}$ & & $\begin{array}{r}9.86 \\
45 \\
\end{array}$ & 0 & & 7.412 & $\begin{array}{c}1.591 \\
5\end{array}$ & 34 & 0 & 143.28 & 509.44 & $\begin{array}{c}.2487 \\
5 \\
\end{array}$ & $\begin{array}{c}0.149 \\
25 \\
\end{array}$ & 2.68 & $\begin{array}{l}5.0- \\
15.0 \\
\end{array}$ & \\
\hline .63 & 169 & & \begin{tabular}{|c|}
15.22 \\
35 \\
\end{tabular} & 582 & & .178 & $\begin{array}{l}1.292 \\
5 \\
\end{array}$ & \begin{tabular}{|c|}
57.0234 \\
5 \\
\end{tabular} & 0 & \begin{tabular}{|c|}
201.98 \\
5 \\
\end{tabular} & & 34 & $\begin{array}{l}0.159 \\
2 \\
\end{array}$ & & $.0-1.5$ & \\
\hline 57 & $\begin{array}{l}.676 \\
45 \\
\end{array}$ & & \begin{tabular}{|c|}
16.61 \\
65 \\
\end{tabular} & 3.781 & & 969 & 377 & & 0 & 8.9 & .15 & 796 & $\begin{array}{l}.159 \\
2\end{array}$ & 333 & $\begin{array}{c}500-2 \\
000\end{array}$ & is \\
\hline .56 & $\begin{array}{l}.681 \\
4 \\
\end{array}$ & & \begin{tabular}{|c|}
17.55 \\
18 \\
\end{tabular} & \begin{tabular}{|c|c|}
11.14 \\
4
\end{tabular} & & 5.964 & $\begin{array}{c}193.32 \\
85 \\
\end{array}$ & & 0 & .87 & 5.01 & 94 & 2 & & 200 & \\
\hline $\begin{array}{l}106.4 \\
65 \\
\end{array}$ & 9.154 & & \begin{tabular}{|c|}
19.06 \\
42 \\
\end{tabular} & \begin{tabular}{|c|}
19.60 \\
15 \\
\end{tabular} & & \begin{tabular}{|l}
0.247 \\
5 \\
\end{tabular} & $\begin{array}{c}208.25 \\
35 \\
\end{array}$ & .625 & 6 & 224.87 & $\begin{array}{c}603.96 \\
5 \\
\end{array}$ & 0845 & \begin{tabular}{|c}
0.159 \\
2 \\
\end{tabular} & \begin{tabular}{|c|}
3.0989666 \\
67 \\
\end{tabular} & 200 & tal \\
\hline 19.4 & \begin{tabular}{|c|}
11.14 \\
4 \\
\end{tabular} & & \begin{tabular}{|c|}
22.60 \\
64 \\
\end{tabular} & \begin{tabular}{|c|}
21.19 \\
35 \\
\end{tabular} & & \begin{tabular}{|l|}
3.978 \\
5 \\
\end{tabular} & 224.87 & 133.33 & 3.9489 & 242.78 & $\begin{array}{c}603.96 \\
5 \\
\end{array}$ & 2685 & $\begin{array}{c}0.248 \\
75 \\
\end{array}$ & \begin{tabular}{|c|}
3.3988666 \\
67 \\
\end{tabular} & 50 & 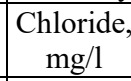 \\
\hline $\begin{array}{l}38.3 \\
05\end{array}$ & $\begin{array}{c}1.3 \\
3\end{array}$ & & \begin{tabular}{|c|}
23.60 \\
14 \\
\end{tabular} & $\begin{array}{r}28 . \\
88 \\
\end{array}$ & & .6 & \begin{tabular}{|c|}
25.46 \\
45 \\
\end{tabular} & \begin{tabular}{|c|}
165.866 \\
5
\end{tabular} & 59.7 & 3.55 & $\begin{array}{c}896.49 \\
5\end{array}$ & 567 & $\begin{array}{c}0.278 \\
6\end{array}$ & $\begin{array}{c}4.5984666 \\
67\end{array}$ & 200 & 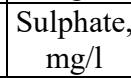 \\
\hline $\begin{array}{l}40.2 \\
95\end{array}$ & $\begin{array}{l}3.92 \\
95 \\
\end{array}$ & & \begin{tabular}{|c|}
24.43 \\
72 \\
\end{tabular} & \begin{tabular}{|c|}
28.15 \\
85 \\
\end{tabular} & & 2 & \begin{tabular}{|c|}
325.96 \\
2 \\
\end{tabular} & \begin{tabular}{|c|}
177.010 \\
5 \\
\end{tabular} & 60.8144 & 8.3 & $\begin{array}{c}1207.9 \\
3 \\
\end{array}$ & 655 & $\begin{array}{c}.278 \\
6 \\
\end{array}$ & & 75 & $\begin{array}{l}\text { Calcium } \\
\mathrm{mg} / \mathrm{l}\end{array}$ \\
\hline $\begin{array}{l}140.2 \\
95\end{array}$ & $\begin{array}{l}5.02 \\
4 \\
\end{array}$ & & \begin{tabular}{|c|}
27.42 \\
22 \\
\end{tabular} & \begin{tabular}{|c|}
32.43 \\
7 \\
\end{tabular} & & דודו. & \begin{tabular}{|l}
10.13 \\
9 \\
\end{tabular} & \begin{tabular}{|c|}
222.203 \\
4 \\
\end{tabular} & 62.287 & 45.76 & $\begin{array}{c}1207.9 \\
3\end{array}$ & 7.761 & $\begin{array}{c}0.308 \\
45 \\
\end{array}$ & 4.070 & 30 & $\begin{array}{l}\text { Magnesi } \\
\mathrm{m}, \mathrm{mg} / \mathrm{l}\end{array}$ \\
\hline $\begin{array}{l}48.7 \\
5 \\
\end{array}$ & $\begin{array}{l}1.85 \\
94\end{array}$ & 11.542 & \begin{tabular}{|c|}
31.04 \\
4 \\
\end{tabular} & $\begin{array}{c}34.02 \\
9 \\
\end{array}$ & 36.019 & $\begin{array}{c}38.40 \\
45 \\
\end{array}$ & 413.92 & \begin{tabular}{|c|}
253.287 \\
2 \\
\end{tabular} & 126.365 & 509.44 & $\begin{array}{c}1214.8 \\
95 \\
\end{array}$ & 8.8555 & \begin{tabular}{|c|}
1.134 \\
3 \\
\end{tabular} & 5.3982 & 0.3 & Iron, $\mathrm{ms}$ \\
\hline
\end{tabular}


International Journal of Science and Research (IJSR)

ISSN (Online): 2319-7064

Index Copernicus Value (2015): 78.96 | Impact Factor (2015): 6.391

\begin{tabular}{|c|c|c|c|c|c|c|c|c|c|c|c|c|c|c|c|c|}
\hline $\begin{array}{c}252.7 \\
3\end{array}$ & $\begin{array}{c}57.31 \\
2\end{array}$ & 11.7012 & $\left|\begin{array}{c}38.11 \\
845\end{array}\right|$ & $\begin{array}{c}44.95 \\
41\end{array}$ & 37.014 & $\mid \begin{array}{c}143.67 \\
8\end{array}$ & $\mid \begin{array}{c}458.69 \\
5\end{array}$ & $\left|\begin{array}{c}282.689 \\
45\end{array}\right|$ & $\mid \begin{array}{c}150.314 \\
65\end{array}$ & 531.33 & $\begin{array}{c}1311.4 \\
1\end{array}$ & 9.0545 & \begin{tabular}{|c}
1.293 \\
5
\end{tabular} & $\left|\begin{array}{c}6.0979666 \\
67\end{array}\right|$ & 20 & \begin{tabular}{|} 
Sodium, \\
$\mathrm{mg} / \mathrm{l}$
\end{tabular} \\
\hline 2587 & $\begin{array}{c}59.99 \\
85\end{array}$ & 130345 & $\begin{array}{c}42.08 \\
85\end{array}$ & $\begin{array}{c}47.08 \\
34\end{array}$ & 398995 & \begin{tabular}{|c|}
192.63 \\
2
\end{tabular} & $\begin{array}{c}717.39 \\
5\end{array}$ & 284.57 & 16517 & 58506 & $\begin{array}{c}1355.1 \\
9\end{array}$ & 9154 & $\begin{array}{c}1.691 \\
5\end{array}$ & $\begin{array}{c}6.1979333 \\
33\end{array}$ & $20 \mathrm{mg}$ & Potassiu \\
\hline $\begin{array}{c}269.6 \\
45\end{array}$ & $\begin{array}{c}83.26 \\
16\end{array}$ & 13.6116 & $\left|\begin{array}{c}43.39 \\
195\end{array}\right|$ & $\begin{array}{c}55.48 \\
12\end{array}$ & 44.1382 & $\begin{array}{c}05.76 \\
6\end{array}$ & \begin{tabular}{|c|}
748.53 \\
85
\end{tabular} & 377.105 & 211.935 & $\begin{array}{c}641.77 \\
5\end{array}$ & $\begin{array}{c}1721.3 \\
5\end{array}$ & 9.4525 & 3.184 & $\left|\begin{array}{c}6.3978666 \\
67\end{array}\right|$ & 2 & $\begin{array}{c}\text { Silica } \\
\left(\begin{array}{c}\mathrm{SiO} 2), \mathrm{m} \\
\mathrm{g} / \mathrm{l}\end{array}\right.\end{array}$ \\
\hline $\begin{array}{c}287.5 \\
55\end{array}$ & $\begin{array}{c}85.76 \\
9\end{array}$ & 13.72105 & 45.77 & $\begin{array}{c}184.0 \\
75\end{array}$ & 199.995 & \begin{tabular}{|l|}
837.79 \\
\end{tabular} & \begin{tabular}{|c|}
2772.0 \\
7
\end{tabular} & 432.825 & 225.865 & $\begin{array}{c}2858.6 \\
35\end{array}$ & $\begin{array}{c}4489.4 \\
4\end{array}$ & 28.855 & $\begin{array}{c}18.90 \\
5\end{array}$ & $\begin{array}{c}6.3978666 \\
67\end{array}$ & $\begin{array}{c}28-178 \\
\text { ppm }\end{array}$ & $\begin{array}{l}\mathrm{COD}, \\
\mathrm{mg} / \mathrm{l}\end{array}$ \\
\hline
\end{tabular}

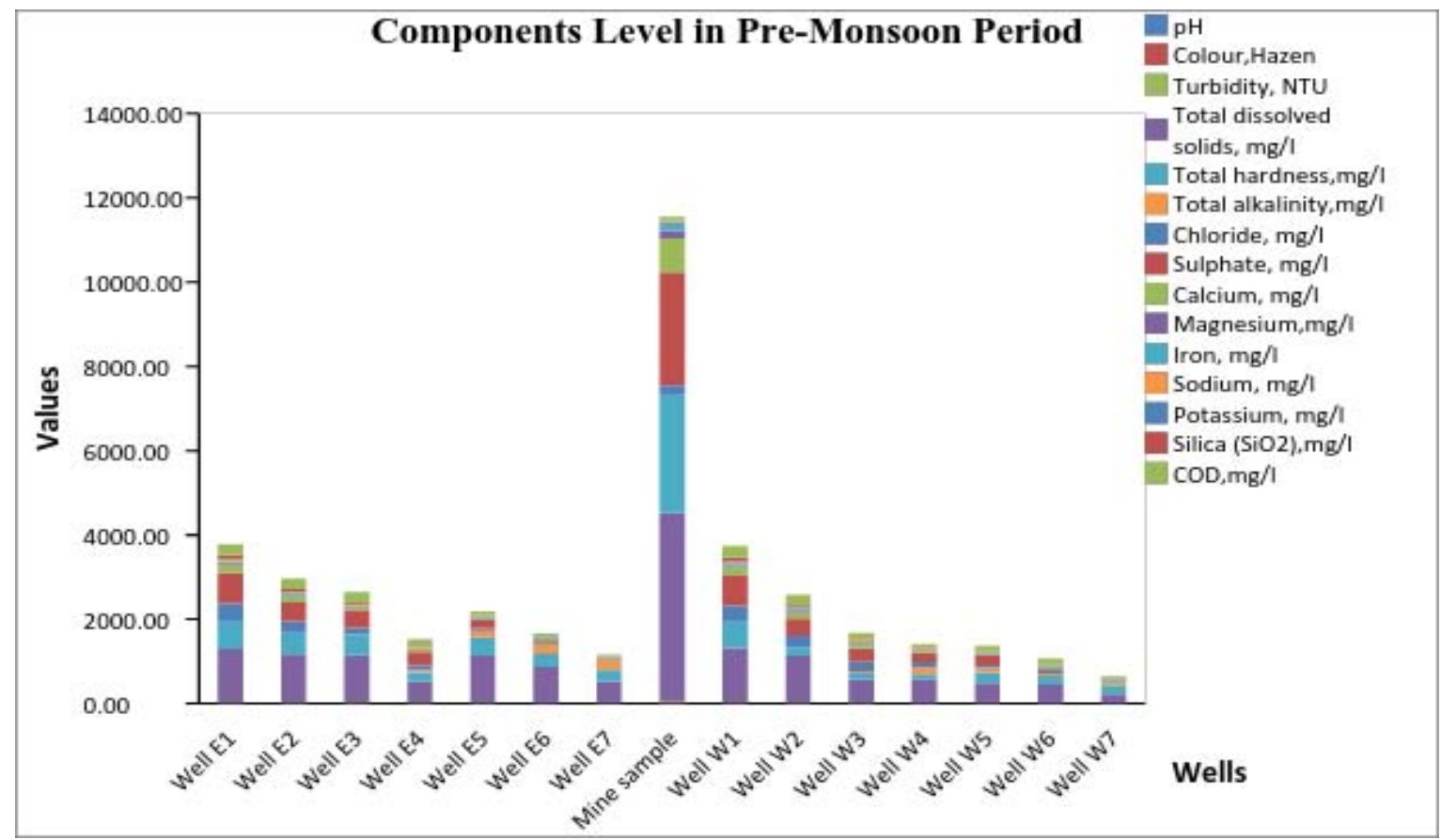

Figure 1: Representation of physicochemical parameters pre-monsoon

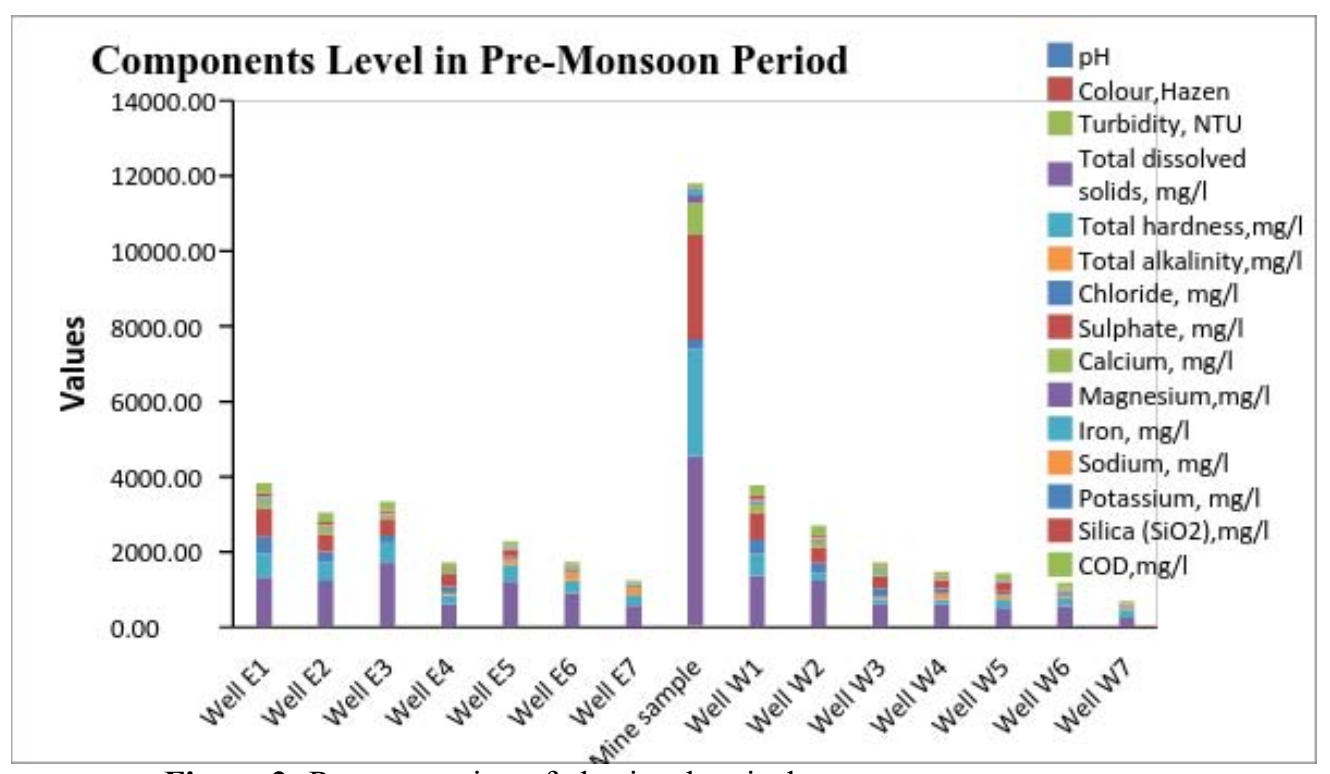

Figure 2: Representation of physicochemical parameters post-monsoon 
International Journal of Science and Research (IJSR)

ISSN (Online): 2319-7064

Index Copernicus Value (2015): 78.96 | Impact Factor (2015): 6.391

Mine sample (MAY 2015)
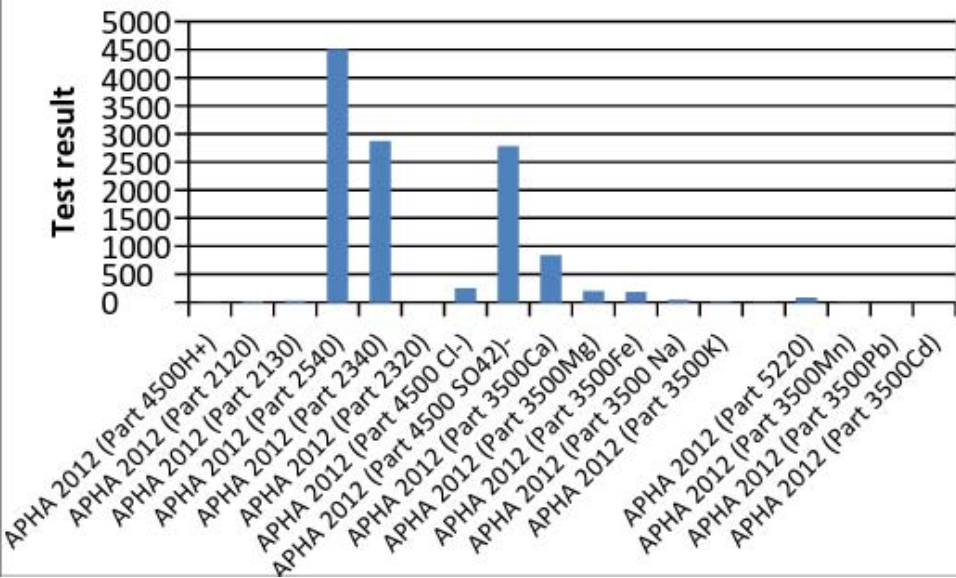

Figure 3: Mine samples (May 2015)

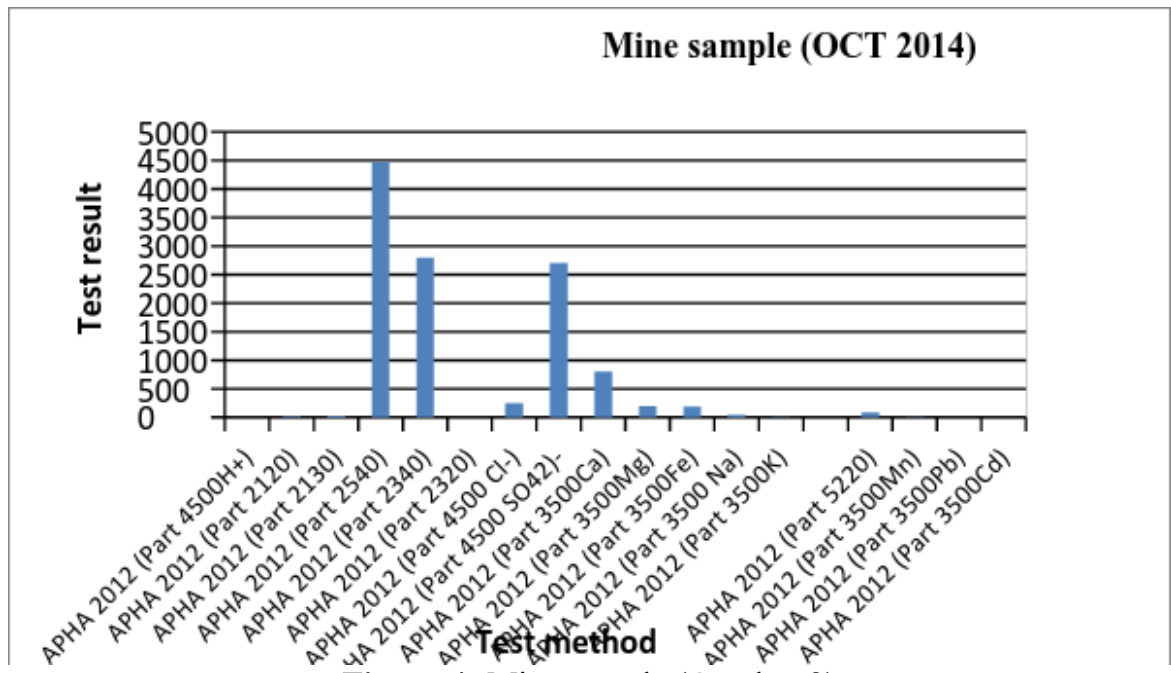

Figure 4: Mine sample (October 2)

Volume 6 Issue 1, January 2017 www.ijsr.net 